process is on $\theta$ of the functions of the reticulo-endothelial system.

A detailed report of this work will be published in the Acta Morphologica Hungarica.

$$
\begin{aligned}
& \begin{array}{c}
\text { Institute of Histology and Embryology, } \\
\text { Medical University, }
\end{array} \\
& \text { Z. Pósalaky } \\
& \text { I. Tönó } \\
& \text { Budapest. } \\
& \text { Oct. } 6 .
\end{aligned}
$$

\title{
Effects of 8-Azaguanine on Sugar Beet infected with Beet Yellows Virus
}

Matrhews has shown ${ }^{1-3}$ that applying the guanine analogue 8-azaguanine (5-amino-7-hydroxy-1-V-triazolo (D) pyrimidine) to Nicotiana spp. infected with lucerne mosaic virus and to $N$. tabacum infected with tobacco mosaic virus delays the onset of symptoms. Over the past two years, we have made similar tests with 8-azaguanine on sugar beet (Beta vulgaris) infected by aphids with beet yellows virus, which, in some years, is the cause of large losses of crop yield in the United Kingdom and other countries. We have observed a delay in the appearance of symptoms of about the same magnitude as those observed with tobacco mosaic virus. Matthews obtained delays in the appearance of symptoms with non-persistent viruses transmitted mechanically, but no such delays occurred when the same viruses were transmitted by aphids. Our results show that a delay can be obtained with a persistent, aphid-transmitted virus.

Using a virulent strain of the virus and three different types of sugar beet of known origin, essentially the same results were obtained in four separate experiments with plants grown in pots in the greenhouse. Seedlings were inoculated at the two-leaf stage by allowing five Myzus persicae (Sulz.) to feed on each plant immediately after feeding on heavily infected plants. Approximately half the plants were treated at three-day intervals with $15 \mathrm{ml}$. of $0.01 \mathrm{M}$ 8-azaguanine dissolved in 0.1 per cent sodium bicarbonate solution. The greater part of this was watered on to the soil and a little sprayed on to the foliage. Small numbers of uninoculated plants were also treated with 8-azaguanine or with sodium bicarbonate only. Two applications of 8-azaguanine were made before inoculation, and there was no evidence that this prevented normal feeding by the aphids. This was confirmed later by the fact that only a very low proportion of the plants proved to be uninfected in any experiment.

Vein-etch symptoms, characteristic of plants infected with necrotic strains of virus yellows, were recorded. These first appeared seven days after inoculation, and afterwards plants were examined daily for symptoms. Symptoms appeared in the untreated plants on the average three to four days earlier than in the treated plants; the plants individually showed delays ranging from one to nine days. The results of one such experiment are set out in Fig. 1.

No stunting was apparent while the symptoms were appearing, but later there was considerable stunting and distortion in the treated plants. It is not certain, therefore, whether the delay in appear. ance of symptoms occurs because the yellows virus is affected directly, or because the growth of the plants is affected.

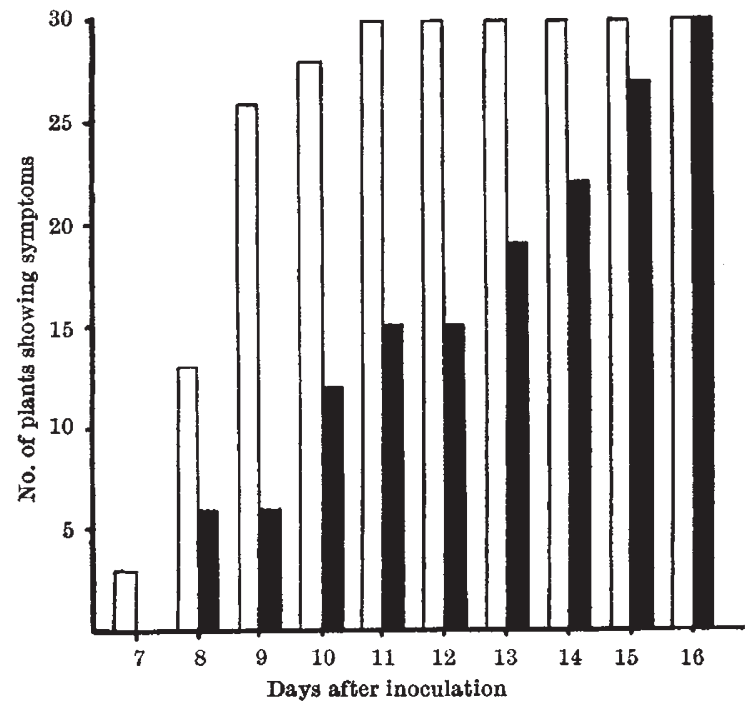

Fig. 1. Effect of 8-azaguanlne on the time of appearance of beet yellows virus symptoms in sugar beet. Open columns, controls (30 plants); solid columns, plants treated with 8-azaguanine (30 plants)

The three beet types so far tested differ in field and glasshouse tolerance, as measured by severity of leaf symptoms and proportional loss of yield on infection. Their reaction to 8-azaguanine treatment after inoculation was very similar; there is, therefore, no indication from these experiments of a relationship between tolerance and delay in appearance of symptoms of infected plants treated with 8-azaguanine.

We are much indebted to Dr. R. E. F. Matthews for his interest, and for making it possible for us to obtain samples of 8-azaguanine through the generosity of the American Cyanamid Company. G. E. Russent

Plant Breeding Institute, A. R. Trim Cambridge. Oct. 24.

'Matthews, R. E. F., J. Gen. Microbiol., 8, 277 (1953). ${ }^{2}$ Matthews, R. E. F., J. Gen. Microbiol., 10, 521 (1954). 'Matthews, R. E. F., Nature, 167, 892 (1951).

\section{Reversal of Phototaxis in the Larvo of Polydora pulchra, Carazzi (Polychæta, Spionida)}

Reversal of phototaxis has been noted in a number of animals and attributed to fright, hunger and food and other chomical stimuli. The only case known to me in which the direction of phototaxis is determined by the salinity of the environment is provided by the larvæ of Polydora pulchra, Carazzi, previously recorded ${ }^{1}$ from the plaice ponds at the Marine Biological Station, Port Erin. The larvæ, which ranged in size from $0.5 \mathrm{~mm}$. to $1.5 \mathrm{~mm}$., were all positively phototactic in solutions of salinity 32.6 per thousand and above, and all negatively phototactic in solutions of salinity 32.5 per thousand and below. Salinities below 30.0 per thousand were lethal within $24 \mathrm{hr}$. In any given salinity the larvæ maintained the same orientation indefinitely or until death, and the behaviour of specimens kept overnight at salinity 4.0 .0 per thousand was afterwards 